\title{
Priority setting for competency development training topics for road construction site managers to reduce the risk of construction failure
}

\author{
Yosritzal $^{1, *}$, Purnawan $^{1}$, Elsa Eka Putri ${ }^{1}$, Evita Kartika Ratu $^{2}$ \\ ${ }^{I}$ Civil Engineering Department, University of Andalas, Main Campus Limau Manis, Padang, 25166, Indonesia \\ ${ }^{2}$ Office of Public Works - Human Settlements and Spatial Planning, Padang, 25138, Indonesia
}

\begin{abstract}
Problem in road construction project could be triggered by employing a less competent Site Manager either in terms of knowledge and skills or in attitudes in the project. Therefore, an evaluation of the competency of the Site Managers and seeking the required development training to improve the relatively weaker items of competency is needed. This paper presents an evaluation of the competency of Site Manager of road construction project in the West Sumatera Road Construction Project 2014. The evaluation was conducted using expectation and performance analysis and the evaluated items of competency were extracted from Indonesian Standard of Competency for Labour especially for Site Manager of Road Construction. The study found that construction management system, project administration, and resource procurement are among competency factors that fall under average and should be improved in the future. Therefore, development training on those items could be initiated by the owner to reduce the risk of road construction project failure in the future.
\end{abstract}

\section{Introduction}

Road construction engineering failure due to the incompetence of the response team for the job may result in a disaster either to the workers, road users, and those who are around the construction site. In order to reduce the risk, Indonesian Standard of Competency for Labour especially for Site Manager of Road Construction (hereafter will be named Site Manager) has been regulating since 2013 [1]. As a consequence, all of the site managers will be assessed based on the standard and those who failed to satisfy the requirement would not be allowed to stay at their position in the future project. In fact, as the standard has just been launched, only a few people who have been passed the assessment and been certified. It is much challenging to find a person who has been certified in a region far from the state capital such as West Sumatera Province - Indonesia and if the assessment being conducted now, the number of Site Managers who will pass the assessment cannot be predicted. Running some competency development training might be very useful in increasing the competency level of the person. However, a limited available budget encourages the authorities to determine what training is in priority to run.

This paper presents the use of ExpectationPerformance Analysis (EPA) in evaluating the competency of the site managers who involved in West Sumatera Provincial Road Project - Indonesia during 2014 and determine the gap between the expected and the perceived performance of them in the owner point of view. Site Managers were the object of this study. Further, this study identifies items of competency to be improved in a competency development training.

\section{Literature review}

\subsection{Indonesia standard of competency for labour}

The establishment of the ASEAN Economic Community in 2015 increases the opportunity for Indonesian workers to work in any ASEAN countries as long as they satisfy the requirement for the job and win the competition. In order to promote fairness in the competition for finding a job between local, and foreign labor, Indonesian Minister of Labour regulates Indonesian Competency Standard for Worker on many job titles. Included in this standard, the minimum level of knowledge, skills, and attitudes to be mastered by every labor.

In road construction work especially for the position of Site Manager, the standard has been regulated since 2013 namely Indonesian Standard of Competency for Road Construction Site Manager 2013 [1]. In terms of knowledge, there are at least 41 items of competency mentioned in the standard which grouped into 9 categories i.e. competency in managing project to satisfy the requirement of the contract, organising site work activities, managing all of available resources,

\footnotetext{
Corresponding author: yosritzal@eng.unand.ac.id
} 
controlling the working method, evaluating effectivity and efficiency of the works, implementing administration procedures, implementing management system, negotiation technique for community relationship and procurement of goods and services. Similarly, in terms of skills, there are 42 items grouped into 8 categories. The selected items of the standard will be used in our questionnaire to assess the expected and the perceived performance of the Site Managers in owner point of view.

\subsection{Expectation-performance analysis}

Expectation - Performance Analysis (EPA) is a modification of the Importance-Satisfaction Analysis or ISA [2] and the Importance-Performance Analysis or IPA [3]. The ISA and IPA have been used in many studies such as in tourism studies [4,5], supplier performance [6], and in assessing the services of public transport [7-12].

The used of IPA in management and employment services has also been published such as by Chang [13]. Modification of the IPA namely RequirementSatisfaction Analysis (RSA) has been implemented in assessing the competency of personnel of the site staff of the Road Infrastructure, Spatial, and Housing Agency of West Sumatera [14] and in assessing the competency of supervision consultant personnel in West Sumatera Provincial Road Construction Project [15]. Despite Sever [16] proposed an improvement to the IPA and [11] discusses the limitation of the IPA, the used of RSA in both Juwita [14] and Yosritzal [15] revealed that the ISA or its modification such as IPA, RSA, and EPA could be used for the perceived competency assessment. Therefore, the method was used in this study without having many problems.

The first step in carrying out EPA is to generate a list of attributes of the services that are relevant to the objective of the study. The second step is to collect data on the expectation level and perceived performance level of site manager on the assessed attributes using a Likertscale type of questionnaire. The third step is to calculate the statistical properties of the rating for each attribute. The fourth step is to plot either mean or median on a four-quadrant graph separated by a hairline which was set based on the universal mean of the Expectation and Performance. The graph is two-dimensional where the Expectation scale represents the vertical axis and the Performance constitutes the horizontal axis as shown in Fig. 1. Attributes residing in the first quadrant (top right) exhibit a higher expectation and higher performance. This quadrant is labeled "keep up the good work" which means that level of service provision or response to consumer issues should continue to be maintained. The second quadrant is labeled as "overkill" because the attributes in this quadrant have a lower level of expectation and a higher level of performance. The lower expectation of the attributes in this quadrant may be because the expectation for this service is met and costumers are satisfied. The attributes in the third quadrant are considered of lower expectation and lower performance and labeled "low priority." The last quadrant is labeled as "concentrate here" as the attributes have a higher expectation but lower performance. To obtain maximum benefit, items in this quadrant should be given a top priority.

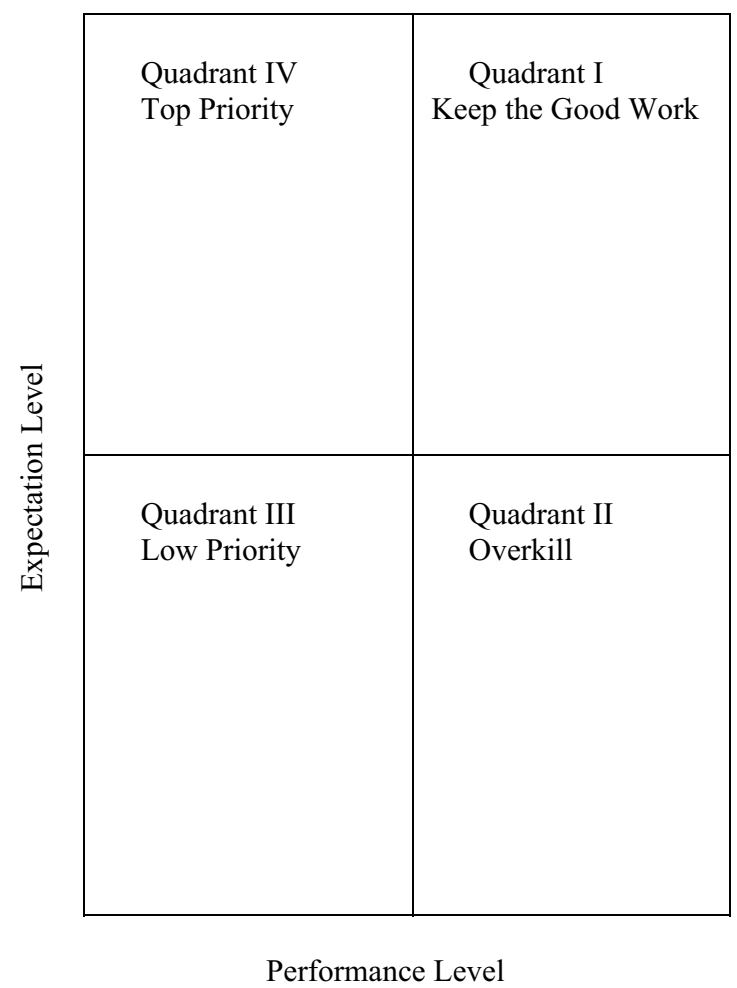

Fig. 1. Expectation-performance matric (modified from [2])

\subsection{Customer satisfaction index}

In order to estimate the overall satisfaction of the owner to the work of the Site Manager, a Customer Satisfaction Index (CSI) was used. The CSI was measured based on the following steps [17]:

1. Calculate the mean important score (MIS) for all evaluated factors and calculate the sum of MIS (Total MIS).

2. Calculate weight importance factor (WF) as a percentage of MIS over Total MIS.

3. Calculate the weighted score (WS) as multiplication of WF by mean satisfaction score (MSS) for each factor.

4. Calculate weighted average total (WAT) as a sum of all weighted score (WS).

5. Calculate customer satisfaction index (CSI) as the ratio between weighted average total (WAT) and high scale (HS) where HS is the maximum rating score.

In order to obtain the qualitative meaning of the CSI, we adopted the criterion of the qualitative academic score used in Academic Regulation of Andalas University [19] as shown in Table 1. 
Table 1. Interval of qualitative scale satisfaction

\begin{tabular}{|c|c|c|c|}
\hline \multicolumn{3}{|c|}{ Score in Academic Regulation } & \multirow{2}{*}{$\begin{array}{c}\text { Score in } \\
\text { Satisfaction } \\
\text { Level } \\
\end{array}$} \\
\hline $\begin{array}{l}\text { Quality } \\
\text { rate }\end{array}$ & Interval & Predicate & \\
\hline $\mathrm{E}$ & $\leq 40 \%$ & Failed & $\begin{array}{c}0 \% \leq X<40 \% \\
\text { (Very Un- } \\
\text { satisfied) }\end{array}$ \\
\hline $\mathrm{D}$ & $40 \% \leq X<50 \%$ & $\begin{array}{c}\text { Not } \\
\text { Adequate }\end{array}$ & $\begin{array}{c}40 \% \leq \mathrm{X}<50 \% \\
\text { (Un-satisfied) }\end{array}$ \\
\hline $\mathrm{C}-$ & $50 \% \leq X<55 \%$ & $\begin{array}{c}\text { Nearly } \\
\text { Adequate }\end{array}$ & \multirow{3}{*}{$\begin{array}{c}50 \% \leq \mathrm{X}<65 \% \\
\text { (Almost } \\
\text { Satisfied) }\end{array}$} \\
\hline $\mathrm{C}$ & $55 \% \leq X<60 \%$ & Adequate & \\
\hline $\mathrm{C}+$ & $60 \% \leq X<65 \%$ & $\begin{array}{c}\text { More than } \\
\text { Adequate }\end{array}$ & \\
\hline B- & $65 \% \leq X<70 \%$ & $\begin{array}{c}\text { Almost } \\
\text { Good }\end{array}$ & \multirow[t]{3}{*}{$\begin{array}{c}65 \% \leq \mathrm{X}<80 \% \\
\text { (Satisfied) }\end{array}$} \\
\hline $\mathrm{B}$ & $70 \% \leq X<75 \%$ & Good & \\
\hline $\mathrm{B}+$ & $75 \% \leq X<80 \%$ & $\begin{array}{l}\text { Very } \\
\text { Good }\end{array}$ & \\
\hline A- & $80 \% \leq X<85 \%$ & $\begin{array}{l}\text { Almost } \\
\text { Perfect }\end{array}$ & \multirow{2}{*}{$\begin{array}{c}80 \% \leq X< \\
100 \% \text { (Very } \\
\text { Satisfied) }\end{array}$} \\
\hline A & $\begin{array}{c}85 \% \leq X \\
<100 \%\end{array}$ & Perfect & \\
\hline
\end{tabular}

Source: [19]

\subsection{Classification of contractors}

Contractors in Indonesia are classified into Small Enterprise and Non-Small Enterprise Contractor [18]. The characteristics of each are shown in Table 2.

Table 2. Classification of contractors and its characteristics

\begin{tabular}{|r|l|l|l|}
\hline No. & \multicolumn{1}{|c|}{ Criteria } & $\begin{array}{l}\text { Small } \\
\text { Contractor }\end{array}$ & \multicolumn{1}{|c|}{$\begin{array}{l}\text { Non-Small } \\
\text { Contractor }\end{array}$} \\
\hline 1 & $\begin{array}{l}\text { Business } \\
\text { Capital }\end{array}$ & $\begin{array}{l}\text { Less than 1 } \\
\text { Billion } \\
\text { Rupiahs }\end{array}$ & $\begin{array}{l}\text { Greater than 1 } \\
\text { Billion Rupiahs }\end{array}$ \\
\hline 2 & $\begin{array}{l}\text { The } \\
\text { requirement } \\
\text { for } \\
\text { Agency the }\end{array}$ & $\begin{array}{l}\text {-PJBU } \\
\text {-PJT }\end{array}$ & $\begin{array}{l}\text {-PJBU } \\
\text {-PJT } \\
\text {-PJB }\end{array}$ \\
\hline 3 & $\begin{array}{l}\text { Job } \\
\text { specification }\end{array}$ & $\begin{array}{l}\text { - Low Risk } \\
- \text { Using Low } \\
\text { Technology } \\
- \text { Low Budget }\end{array}$ & $\begin{array}{l}\text { - High Risk } \\
\text { - High } \\
\text { Technology } \\
\text { - High Budget }\end{array}$ \\
\hline 4 & $\begin{array}{l}\text { Fundamental } \\
\text { Capacity }\end{array}$ & $\begin{array}{l}\text { KD = 3 NPT } \\
\text { Estimated based } \\
\text { on achievement } \\
\text { year }\end{array}$ \\
\hline
\end{tabular}

This study focuses on the Non-Small Contractors which involved in provincial road project during 2014.

\subsection{Indonesian standard of competency (SKKNI) of site manager}

The items of competency in terms of knowledge are shown in Table 3 [1].
Table 3. Knowledge items of the Indonesian standard of competency

\begin{tabular}{|c|c|c|}
\hline \multicolumn{2}{|c|}{ No. } & Knowledge \\
\hline$I$ & \multicolumn{2}{|c|}{ Contract Document } \\
\hline & 01 & Contract Agreement \\
\hline & 02 & Contract Requirement \\
\hline & 03 & Technical Specification \\
\hline & 04 & Engineering Drawing \\
\hline & 05 & Construction Services Regulation \\
\hline II & \multicolumn{2}{|r|}{ Site Engineering } \\
\hline & 01 & $\begin{array}{l}\text { Analysis and Evaluation of Survey Result of the } \\
\text { Site }\end{array}$ \\
\hline & 02 & $\begin{array}{l}\text { Analysis and Evaluation of Survey Result of the } \\
\text { Site Entry Point }\end{array}$ \\
\hline & 03 & $\begin{array}{l}\text { Analysis and Evaluation of Survey Result of the } \\
\text { Location and Quality of Raw Material }\end{array}$ \\
\hline & 04 & Knowledge of Social, Culture, and Security \\
\hline & 05 & Value engineering \\
\hline & 06 & Re-design \\
\hline III & \multicolumn{2}{|r|}{ Road Construction Methods } \\
\hline & 01 & Flexible pavement construction methods \\
\hline & 02 & Rigid pavement construction methods \\
\hline & 03 & $\begin{array}{l}\text { Construction methods for complementary } \\
\text { building and retaining wall }\end{array}$ \\
\hline & 04 & $\begin{array}{l}\text { Construction methods for Health and Safety in } \\
\text { the work zone }\end{array}$ \\
\hline & 05 & $\begin{array}{l}\text { Controlling of Environment impacts and } \\
\text { security }\end{array}$ \\
\hline & 06 & Traffic management in the work zone \\
\hline IV & \multicolumn{2}{|r|}{ Bridge Construction Methods } \\
\hline & 01 & Construction methods for the bridge foundation \\
\hline & 02 & $\begin{array}{l}\text { Construction methods for the lower structure of } \\
\text { the bridge }\end{array}$ \\
\hline & 03 & $\begin{array}{l}\text { Construction methods for upper structure of a } \\
\text { bridge }\end{array}$ \\
\hline & 04 & $\begin{array}{l}\text { Construction methods for the complementary } \\
\text { building of a bridge }\end{array}$ \\
\hline$V$ & \multicolumn{2}{|r|}{ Road construction cost estimation } \\
\hline & 01 & Estimation of road construction cost \\
\hline & 02 & Optimisation of road construction cost \\
\hline$V I$ & \multicolumn{2}{|r|}{ Bridge construction cost estimation } \\
\hline & 01 & Estimation of bridge construction cost \\
\hline & 02 & Optimisation of bridge construction cost \\
\hline$V I I$ & \multicolumn{2}{|r|}{ Controlling Quality, schedule, and cost } \\
\hline & 01 & Quality control of road construction work \\
\hline & 02 & Schedule control of road construction work \\
\hline & 03 & Cost control of road construction work \\
\hline VIII & \multicolumn{2}{|r|}{ Construction management system } \\
\hline & 01 & The concept of construction management system \\
\hline & 02 & Resources management \\
\hline & 03 & Process management of quality and schedule \\
\hline & 04 & Leadership in ethics and work culture \\
\hline & 05 & Information and communication system \\
\hline$I X$ & \multicolumn{2}{|r|}{ Project administration } \\
\hline & 01 & Project administration \\
\hline & 02 & General administration \\
\hline & 03 & Financial administration \\
\hline & 04 & Administrating and reporting \\
\hline$X$ & \multicolumn{2}{|c|}{ Negotiation and public relation } \\
\hline & 01 & Negotiation techniques \\
\hline & 02 & Social, cultural and public relation \\
\hline & 03 & Implement good corporate governance \\
\hline$X I$ & \multicolumn{2}{|r|}{ Resources procurement } \\
\hline & 01 & Construction service procurement \\
\hline & 02 & Goods procurement \\
\hline
\end{tabular}




\section{Methodology}

Data for this study was collected in 2015 by distributing a questionnaire to officers from Road Infrastructure and Settlement Agency who involved in provincial road construction on behalf of Owner of the project. The questionnaire was designed to obtain respondents' identity and their perceived level of expectation and level of performance of Site Managers of the 2014 Provincial Road Construction Project regarding every item of competency evaluated. The statements were compiled based on the items in the Indonesian Standard of Competency of Site Manager. Respondents rated their perceived level of the expectation and the performance in a Five-point Likert-scale where 1 represented the lowest and 5 represented the highest. Data were analyzed using descriptive analysis and Expectation-Performance Analysis as discussed in Section 2. Cronbach Alpha Test was performed in order to test the reliability and validity of each item.

The scores used for the EPA were the average score per group of competency items for all respondents. For example, a contract document in the first group consists of five items. All respondents answered all the items. The average of the score for each item was calculated across all respondents and then was the average of the average was calculated across the item in the group. A group of competency items for bridge construction in Table 3 was omitted from our questionnaire, therefore, in the EPA.

\section{RESULT}

\subsection{Description of the object study}

The object of the study is the competency of contractor personnel who involved in Provincial Road Project in 2014 as Site Manager. During 2014, there were 9 projects separated in 25 packages for Non-Small and 7 packages for Small Contractors. The study focuses on the non-small contractors as it involved in large-scale projects. In total, 22 Non-Small Contractors were involved, 2 of them were involved in more than one packages.

\subsection{Respondents' characteristics}

Respondents for this study are the persons who are responsible for the 2014 Provincial Road Project and acted as the owner of the project on behalf of the West Sumatera Road Infrastructure and Settlement Agency. In total, there were 26 people involved which consisted of 8 Top Executive Officers, 9 Head of Technical Affairs (KAURs) and 9 Inspectors.

In terms of age, 57 percent have aged 50 years or more and 43 percent under 50 years old. In term of work experience, 54 percent has more than 10 years of work experience. In terms of education, our respondents are educated people with $66 \%$ have a university degree and $34 \%$ graduated from a senior high school with $10 \%$ graduated from a postgraduate program. These profiles showed that the respondents are worth believing as they are educated and experienced in their field(Fig. 2.).

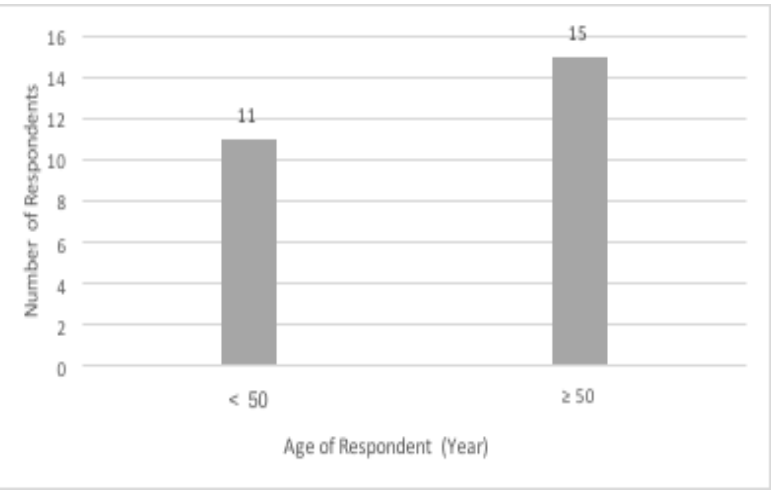

( a )

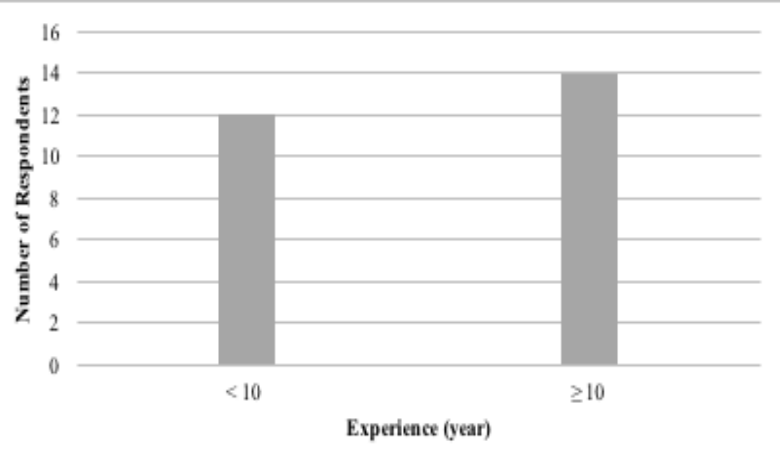

( b )

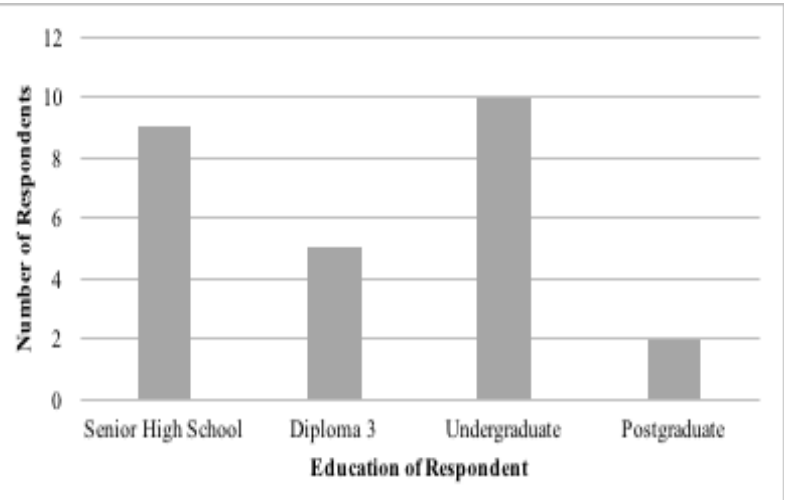

(c)

Fig. 2. The characteristics of respondents. (a) by age group. (b) by experiences and (c) by educations.

\subsection{CSI score}

The CSI is $69 \%$ as shown in Table 4 and fall into level 4 at the interval of $65 \%<C S I \leq 80 \%$ which is categorized as Satisfied. This means that the owner is satisfied with the performance of the contractors who did the road provincial road construction. 
Table 4. CSI scores

\begin{tabular}{|c|l|c|c|c|c|}
\hline No. & \multicolumn{1}{|c|}{ Description } & $M . E$ & $W . E$ & $M . P$ & $W . P$ \\
\hline A & $\begin{array}{l}\text { Contract } \\
\text { Document }\end{array}$ & 3,91 & $10,5 \%$ & 3,38 & 0,353 \\
\hline B & Site Engineering & 4,01 & $10,7 \%$ & 3,50 & 0,376 \\
\hline C & $\begin{array}{l}\text { Road Construction } \\
\text { Methods }\end{array}$ & 4,21 & $11,3 \%$ & 3,48 & 0,392 \\
\hline D & $\begin{array}{l}\text { Road construction } \\
\text { cost estimation }\end{array}$ & 4,02 & $10,8 \%$ & 3,60 & 0,387 \\
\hline E & $\begin{array}{l}\text { Controlling } \\
\text { Quality, schedule, } \\
\text { and cost }\end{array}$ & 4,22 & $11,3 \%$ & 3,51 & 0,396 \\
\hline F & $\begin{array}{l}\text { Construction } \\
\text { management } \\
\text { system }\end{array}$ & 4,25 & $11,4 \%$ & 3,36 & 0,382 \\
\hline G & $\begin{array}{l}\text { Project } \\
\text { administration and } \\
\text { documentation }\end{array}$ & 4,47 & $12,0 \%$ & 3,31 & 0,396 \\
\hline H & $\begin{array}{l}\text { Negotiation and } \\
\text { public relation }\end{array}$ & 4,04 & $10,8 \%$ & 3,50 & 0,378 \\
\hline I & $\begin{array}{l}\text { Resources } \\
\text { procurement }\end{array}$ & 4,25 & $11,4 \%$ & 3,22 & 0,366 \\
\hline Total = & 37,38 & $100 \%$ \\
\hline Weighted Total Score $=$ \\
\hline Satisfaction Index $=$ & \multicolumn{3}{|l}{} \\
\hline
\end{tabular}

$$
\begin{aligned}
& \text { Note: } \text { M. } E=\text { Mean of Expectation } \\
& \text { W.E }=\text { Weighted Expectation } \\
& \text { M. } P=\text { Mean of Performance } \\
& \text { W. } P=\text { Weighted Performance }
\end{aligned}
$$

\subsection{Requirement satisfaction analysis}

Prior to the EPA, a Cronbach Alpha reliability test was conducted to ensure all of the questions are reliable. It was found that the reliability for the performance and the expectation were 0,930 and 0.886 respectively. As the Cronbach Alpha is higher than 0.70, it can be concluded that both data groups are reliable to be analyzed further with EPA. The quadrant analysis result of EPA is shown in Fig. 3.

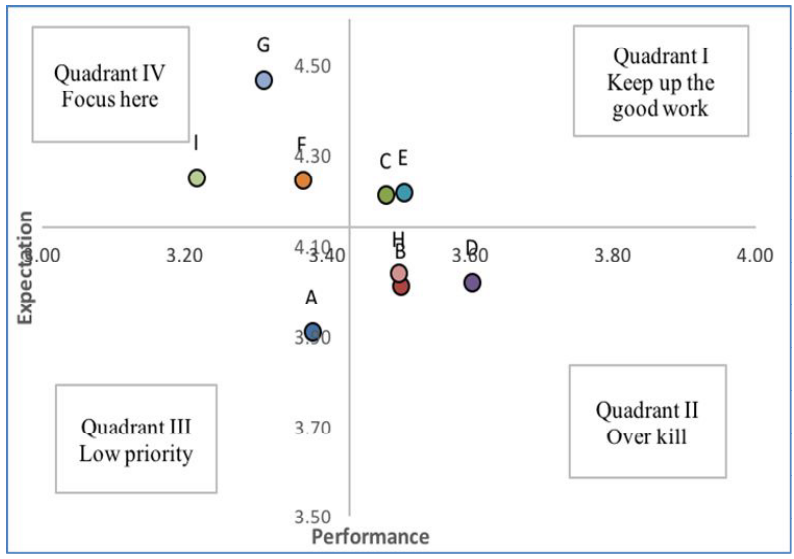

Fig. 3. Expectation-performance analysis

Fig. 3. shows the map of the 9 points of competency on four quadrants. The first quadrant is for items with high expectation and very well performed; second quadrants is for items with low expectation but performed very well; the third quadrant is for items with low expectation and low performance, and the fourth quadrant is for items with high expectation but not well performed.

The items for each quadrant are as follows:

- Quadrant I (keep up the good works). Items in this quadrant are $\mathrm{C}$ (Road Construction Methods) and $\mathrm{E}$ (Controlling Quality). This finding suggests that contractors are managed to implement a good construction method for road constructions for all aspects of such as rigid and flexible pavement; complementary building and retaining wall; maintaining traffic management, health and safety at work zone with always control the impact to environment and security. Furthermore, contractors were performed very well at the ability to control the quality, schedule, and cost of the construction project. These items are considered as the most important factors in road construction and owner expect a high competency in them. Contractors should keep up their good works for these items.

- Quadrant II (Overkill). Items in this quadrant are item B (Site engineering), D (Road construction cost estimation) and item $\mathrm{H}$ (Negotiation and public relation). Site engineering, estimation of construction cost, negotiation and public relation of contractors were considered by the owner as not so importance competency for Site Managers. However, the contractors maintain a good performance for these items. No action need to take for these items.

- Quadrant III (Low priority). Items A (Contract document) is in this quadrants. The conformity of the structural organization of the contractors with the contract was considered by the owner as not so important for contractors. Even though contractors were perceived not performed well, this item is in a lower priority to improve.

- Quadrant IV (Focus here). Three items are in this quadrant, i.e. F (road construction management system), G (administration and documentation) and item I (Resources procurement). Contractors were performed relatively low but the owner expects a high competency in these items. Contractors were expected to understand the concept of the road construction management system, therefore, they can manage their resources, enhance quality, to uphold ethics and work culture and use a clear information and communication system. Contractors were perceived to have lower skills and knowledge in procurement and project administration and documentation, even though these items are important in road construction. Contractors should increase their ability in these items and the owner should coach the contractors through competency training or in site coaching.

\subsection{Detail items need to improved}

The mean scores for each item in the point F, G and I are shown in Table 5. 
Table 5. Gap Between Expectation and Performance on Point $\mathrm{F}, \mathrm{G}$ and $\mathrm{I}$

\begin{tabular}{|c|c|c|c|c|}
\hline Point & Description & $\mathbf{P}$ & $\mathbf{E}$ & Gap \\
\hline $\mathbf{F}$ & \multicolumn{4}{|c|}{ Road construction management system } \\
\hline 1 & $\begin{array}{l}\text { The managerial } \\
\text { ability of Project } \\
\text { Leader verbally and } \\
\text { nonverbally. }\end{array}$ & 3,46 & 4,31 & 0,85 \\
\hline 2 & $\begin{array}{l}\text { Conformity of time } \\
\text { schedule }\end{array}$ & 3,29 & 4,35 & 1,06 \\
\hline 3 & $\begin{array}{l}\text { Ethics and working } \\
\text { culture }\end{array}$ & 3,38 & 4,08 & 0,70 \\
\hline 4 & $\begin{array}{l}\text { Availability of } \\
\text { information of project } \\
\text { schedule. }\end{array}$ & 3,34 & 4,08 & 0,74 \\
\hline 5 & $\begin{array}{l}\text { The decision was } \\
\text { made based on data } \\
\text { dan information }\end{array}$ & 3,41 & 4,23 & 0,82 \\
\hline 6 & $\begin{array}{l}\text { Coordination during } \\
\text { the project execution. }\end{array}$ & 3,54 & 4,27 & 0,73 \\
\hline 7 & $\begin{array}{l}\text { The effectiveness of } \\
\text { the equipment }\end{array}$ & 3,50 & 4,46 & 0,96 \\
\hline 8 & $\begin{array}{l}\text { Delivery of material is } \\
\text { properly calculate }\end{array}$ & 3,37 & 4,35 & 0,98 \\
\hline 9 & $\begin{array}{l}\text { The carefully } \\
\text { handling material in } \\
\text { the site }\end{array}$ & 3,43 & 4,15 & 0,73 \\
\hline 10 & $\begin{array}{l}\text { Demand-based } \\
\text { worker distribution }\end{array}$ & 3,28 & 4,19 & 0,92 \\
\hline $\mathbf{G}$ & \multicolumn{4}{|c|}{ Administration and documentation } \\
\hline 11 & $\begin{array}{l}\text { Completeness of the } \\
\text { organization structure } \\
\text { of the project team }\end{array}$ & 3,37 & 4,12 & 0,75 \\
\hline 12 & $\begin{array}{l}\text { Routine and orderly in } \\
\text { administration }\end{array}$ & 3,22 & 4,65 & 1,44 \\
\hline 13 & $\begin{array}{l}\text { Conformity of the } \\
\text { project reports with } \\
\text { the actual conditions } \\
\text { in the site }\end{array}$ & 3,51 & 4,65 & 1,14 \\
\hline 14 & $\begin{array}{l}\text { Integrated } \\
\text { documentation system }\end{array}$ & 3,31 & 4,42 & 1,11 \\
\hline 15 & $\begin{array}{l}\text { The availability of } \\
\text { complete project } \\
\text { documentation of } \\
\text { contractor }\end{array}$ & 3,32 & 4,50 & 1,18 \\
\hline $\mathbf{I}$ & \multicolumn{4}{|l|}{ Resources } \\
\hline 16 & $\begin{array}{l}\text { The provided staff } \\
\text { meets the } \\
\text { requirements }\end{array}$ & 3,36 & 4,27 & 0,90 \\
\hline 17 & $\begin{array}{l}\text { The equipment } \\
\text { provided meets the } \\
\text { needs }\end{array}$ & 3,35 & 4,42 & 1,08 \\
\hline 18 & $\begin{array}{l}\text { Material available on } \\
\text { time and in good } \\
\text { quality }\end{array}$ & 3,26 & 4,27 & 1,01 \\
\hline 19 & $\begin{array}{l}\text { Ownership of } \\
\text { reserved fund and } \\
\text { ready to use }\end{array}$ & 3,06 & 4,04 & 0,98 \\
\hline
\end{tabular}

In Point F, the top three of the highest gap belongs to item conformity of time schedule, the effectiveness of the equipment and delivery of material. It seems that these items are related to each other and could be associated with the competency in scheduling equipment, material, and worker. In point $\mathrm{G}$, the top three are routine and orderly administration, availability of complete project documentation, and the conformity of the project report with the actual condition. These three items might be a confirmation of the lack of knowledge, skills, and attitude in making the right report regularly.

\section{Conclusions and recommendations}

The evaluation of the competency of Site Managers of the 2014 West Sumatera Road-Construction-Projects has been conducted using the expected and performance analysis. The study found that in general, the Customer Satisfaction Index (CSI) for the competency of the Site Managers is $69 \%$ suggesting that the Owner satisfied with their performance. However, there are a lot of things to be improved to rich the highest level of satisfaction $(80 \%$ to $100 \%)$ such as in the construction management system, project administration and resource procurement. The largest gap between the expected level of competency and the performance is the competency in the project administration and documentation. Therefore, a training on the project administration could be initiated by the owner for a better quality of the road construction works in the future and to avoid construction disaster.

The publication of this paper is supported by the Dean of Engineering Faculty of Andalas University through Engineering Faculty Publication Grant 2018 contract number: 32/UN.16.09.D/PL/2018.

\section{References}

1. SKKNI. Site Manajer of Road Construction, Public Works Department. (2013). (In Indonesia)

2. J.A. Martilla and C.J. John. Importance-Performance Analysis. The Journal of Marketing, 41(1), pp. 77-79. (1977)

3. L.A. Graf, M. Hemmasi, and W. Nielsen. Importance-Satisfaction Analysis: A diagnostic tool for organizational change. Leadership \& Organization Development Journal, 13(6), pp. 8-12. (1992).

4. B.B. Boley, N.G. McGehee, and A.L.T. Hammett. Importance-performance analysis (IPA) of sustainable tourism initiatives: The resident perspective. Tourism Management. Vol. 58, February 2017. Pp 66-77. (2017).

5. A. Guizzardi A. and A. Stacchini. Destination strategic groups via multivariate competition-based IPA. Tourism Management. Vol 58. February 2017. Pp 40-50. (2017).

6. L.H. Ho, S.Y. Feng, Y.C. Lee, T.M. Yen. Using Modified IPA to evaluate supplier's performance: regression analysis and DEMATEL approach. Expert Systems with Applications. Vol. 39. Issue 8. 15 Juni 2012. Pp 7102-7109. (2012). 
7. A. Fashalli, Yosritzal, B.M. Adji B.M. The implementation of quadrant analysis in evaluation and improvement of the passenger services of Sibinuang Regular Train. Proceeding $4^{\text {th }}$ Andalas Civil Engineering (ACE) Conference 2017, 9 November 2017, University of Andalas, pp 371-384. (2017). (In Indonesia)

8. P. Astuti, Yosritzal, B.M. Adji. Recommended Policy for Improvement of Infrastructure and Services of Sultan Thaha Airport based on Consumer Satisfaction Analysis. Proceeding $4^{\text {th }}$ Andalas Civil Engineering (ACE) Conference 2017, 9 November 2017, University of Andalas, pp 515-526. (2017). (In Indonesia)

9. D. Hadi, B.M. Adji, Yosritzal. [The implementation of quadrant analysis in evaluation and improvement of the passenger services of the Padang Railway Station. Proceeding $4^{\text {th }}$ Andalas Civil Engineering (ACE) Conference 2017, 9 November 2017, University of Andalas, pp 419-430. (2017). (In Indonesia)

10. Yosritzal, D. Dissanayake, M.C. Bell. ImportanceSatisfaction Analysis of Rail Services in the UK with Respect to Travel Time Use. Proceeding of the $17^{\text {th }}$ FSTPT International Symposium, Jember University, August 23, 2014. (2014a)

11. Yosritzal, B.M. Adji, F. Nofrizal and R. Andika. The implementation of the Importance-Satisfaction Analysis method in the priority setting of the improvement of the Padang-Pariaman Rail Services. Proceeding of the $1^{\text {st }}$ Andalas Civil Engineering (ACE) Conference 2014. November 27, 2014. The University of Andalas. (2014b). (In Indonesia)

12. Yosritzal, Yossyafra, A.S. Yuda. Analysis of the passengers' perception of the services of MV Mentawai Fast. Proceeding of the $18^{\text {th }}$ FSTPT International Symposium, Lampung University, August 28, 2015. (2015). (In Indonesia)

13. Chi-Cheng Chang. Improving employment services management using IPA technique. Expert Systems with Applications. Vol. 40, Issue 17, 1 December 2013. Pp 6948-6954. (2013).

14. W. Juwita, Yosritzal, D. Rinaldi. The leadership assessment study on the level of road technical personnel competence at Department of Infrastructure for Road and Settlement Roads Province of West Sumatera using requirementsatisfaction analysis. Proceeding of the International Conference on Sustainable Civil Engineering Structures and Construction Materials, Special Topic in Public Works Research and Technology. ISBN 978-602-71762-3-2. September 5, 2016. Bali, Indonesia. (2016).

15. Yosritzal, V. Asmery, Purnawan. Competency of West Sumatera Provincial Road Construction Project Supervising Consultants in Owner Perception. International Journal of Civil Engineering \& Technology (IJCIET) - Scopus Indexed.Volume: 8 Issue: 10. Pp 743-752. (2017).

16. I. Sever. Importance-performance analysis: A valid management tool? Tourism Management. Vol. 48. June 2015. Pp 43-53. (2015).
17. R. Khasani. An evaluation of consumer satisfaction on the project management performance of large scale contractors for building construction. Thesis. Universitas Diponegoro. (2013). (In Indonesia)

18. LPJK. Regulation of Construction Service Development Agency No. 02/2011 on re-registration procedures, extension period and New Application of a Construction Service Business. Construction Services Development Agency. Jakarta. (2011). (In Indonesia)

19. Rektor Unand. The regulation of Rector of University of Andalas No. 3/2016 on Academic Regulation of University of Andalas. Padang. Indonesia. (2016). (In Indonesia) 